\title{
ANTI-SPACE: THE POLITICAL COMPLEXION OF AN INNER CITY ART GALLERY
}

\author{
Jonathan P. Vickery \\ Centre for Cultural Policy Studies, University of Warwick, \\ Millburn House, Coventry, West Midlands, CV4 7AL, UK \\ E-mail:j.p.vickery@warwick.ac.uk
}

Received 25 November 2013; accepted 14 February 2014

\begin{abstract}
The subject of this paper is an inner city artist-run gallery called Eastside Projects. As part of an historical trend in artistrun spaces, Eastside Projects have innovated a strategic approach to post-industrial space, their location and role within the city of Birmingham, UK. This paper outlines their approach in the context of the recent cultural policy frameworks impressed on publicly funded city-based art organisations. It attempts to extend the conceptualisation of contemporary art in the city within urban studies generally, specifically investigating the theoretical potential of Eastside Project's curatorial strategy. How can we define public agency for art in the neoliberal city? For Eastside Projects, agency is defined principally through space and the aesthetics of space. This paper proposes a theoretical framework for articulating the political aesthetics of new public spaces for art.
\end{abstract}

Keywords: contemporary art, creative city, cultural policy, public space, spatial aesthetics.

Reference to this paper should be made as follows: Vickery, J. P. 2014. Anti-Space: the political complexion of an inner city art gallery, Journal of Architecture and Urbanism 38(1): 90-101.

\section{Introduction}

Since the 1980s, a substantial amount of research has emerged on the politics of art institutions, museums and galleries, as well as the contemporary art markets (Lind 2010 O'Neill 2012; Rand, Kouris 2007). This emerging scholarship and criticism coincided with the English-language reception of the work of Bourdieu and of Foucault, both of whose influentual conceptualisation of power allowed for the term 'politics' to be routinely applied to every human institution or social activity (Bourdieu 1984; Foucault 1972). In this short investigation, I locate power in a particular variant of art curatorial practice and the space in which it operates. Yet I will not be concerned with the politics of 'art', whether exhibitions and the display of knowledge, art world systems of commercial exchange and distribution, or the power of the European and American art elites that hold power of governance over the global art economy (Buddensieg, Belting 2009). My focus is the space of curatorial practice and the 'political' complexion of an inner city art gallery called Eastside Projects.
My research questions revolve around the relation between the organisational dynamics and artistic aspirations of this new art space. How is the space conceptualised, rationalised, and given an identity within the specific urban and policy contexts of the city? How does a new art space with an explicit commitment to 'public' culture contend with the neoliberal political bent of the cultural policy of the city? The 'cultural politics' of neoliberalism is a research subject yet to be fully explored. Indeed, art institutions in Europe remain remarkably conservative in their management structure and organisational formation, and thereby maintain a somwhat deferent posture towards the demands of cultural policy on both national and local-city levels. Many European cities, of course, have their 'radical' cultural enclaves, dissenting groups and arts of resistance. My interest here, however, is not in a radical artist group, but an organisation in regular receipt of public funding. Eastside Projects, I argue, offer an uncommon opportunity for developing new 


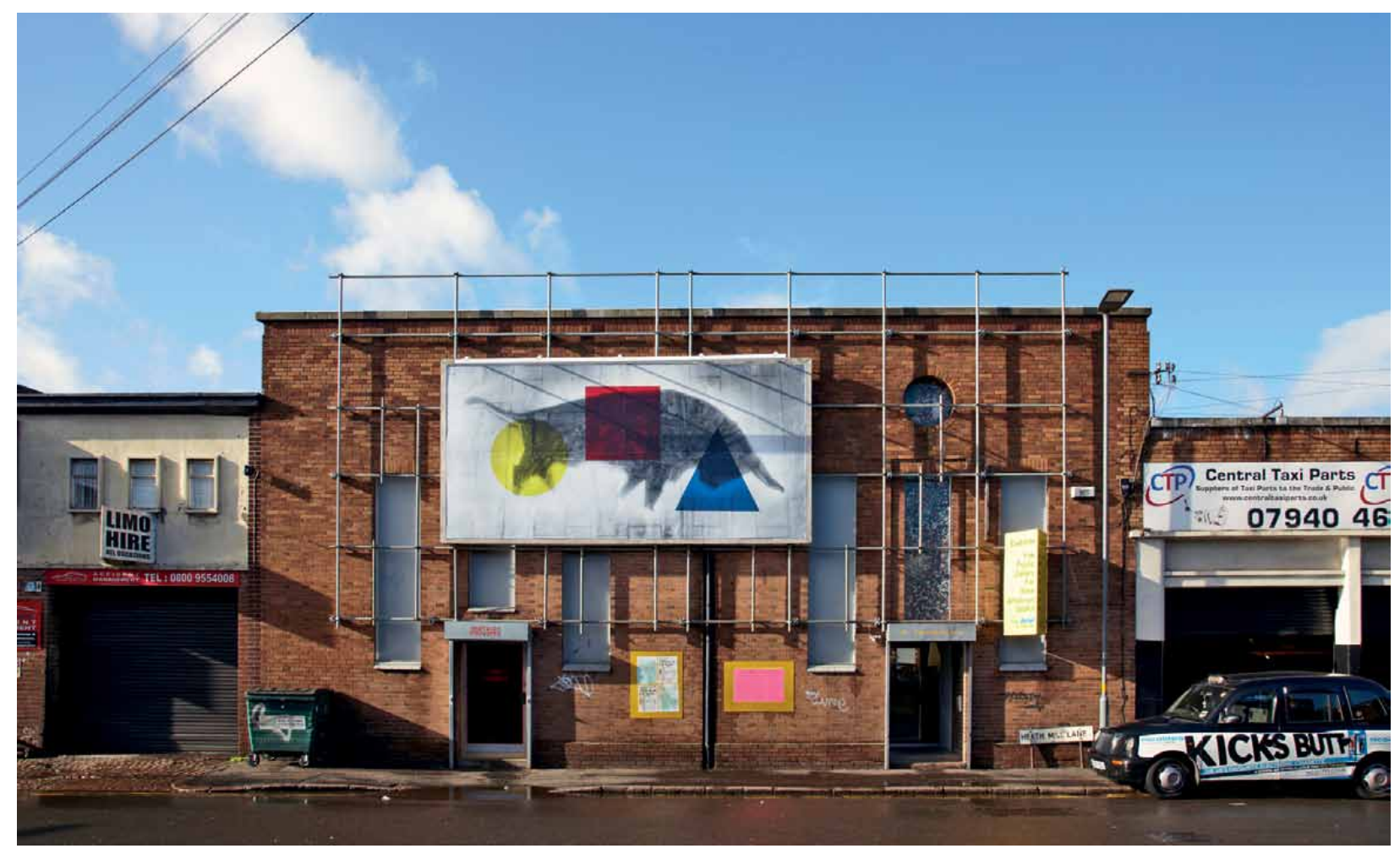

Fig. 1. Eastside Projects (exterior)

lines of critical inquiry into the relation between the political and the spatial aesthetics of new art spaces.

Eastside Projects [hereafter, EP] opened in the summer of 2008. It is housed in a large brick-build industrial unit, providing one main exhibition hall, office and social space, and one adjacent smaller gallery space. It was initiated in collaboration with Arts Council England and Birmingham City University, and then managed by artist-curator Gavin Wade, artists Simon \& Tom Bloor and Ruth Claxton, artist and architect Celine Condorelli, and designer James Langdon. It is revenue funded by Arts Council England as one of just under 700 'National Portfolio Organisations', but has assumed the legal form of a not-for-profit company Ltd by guarantee. It maintains a formal partnership with Birmingham City University, grants from two major philanthropic foundations, receives funds on a project-by-project basis from a variety of collaborators, but altogether the curatorial strategy of the enterprise is entirely independent. Within the city of Birmingham EP now enjoy high visibility as one of two major venues for international contemporary art (Bloor et al. 2011; Wade et al. 2011). They maintain annual revenues of around e300k, with up to 15,000 visitors and facilitate a professional development arm, called Extra Special People (ESP). The gallery's operational rationale is stated on its website: 'We believe in working collaboratively towards change and do so to support the cultural growth of Birmingham. We do not make art for the public. We are the public that makes art. The artist run space is not a stop gap. The artist run space is a public good.' (Eastside Projects: http://eastsideprojects.org/ about/). The detail on EP I convey in this paper is taken from four years of visiting the gallery, exhibitions and events, and interviews with staff: the quotations in the section Two are from a recent interview with artist-curator and main director, Gavin Wade (Vickery 2013).

\section{The artist-run gallery}

A recent historical origin of the artist-run gallery is $\mathrm{New}$ York City. During the latter half of the 1960s, minimalist, conceptual, performance and land artists sought to find in the post-industrial landscape new sites for experimental art practices. A notable moment was 1971, where critic Alanna Heiss founded the Institute for Art and Urban Resources in Queens. For Heiss, new urban locations for the production and dissemination of art would stimulate a rehabilitation in increasingly vacant parts of the city. As Nuno Grande pointed out in his essay 'Relational Critique', the increasing involvement of artists in urban spaces has been concurrent (if not symbiotic with) with the emergence of the 'super-brands' of new style contemporary art museums (Grande 2012). Heiss's Institute became PS.1. Contemporary Art Centre, which after an $\$ 8$ million dollar renovation 
in 2000 became institutionally connected to Museum of Modern Art (MOMA). The year 2000 was the year Tate Modern in London officially opened. The trend for post-industrial art spaces is now global. In China, for example, 'warehouse style art' is spreading to all major cities: In Shanghai, the year 2000 saw the establishment of the M50 art district in Suzhou Creek, now home to 120 galleries and studios. The Power Station of Art, housed in the former Urban Future Pavilion from the 2010 Shanghai World Expo, has recenly opened, supported by the State. Other areas, like the '1933' district, a giant former abattoir and factory, cater for a mixed development of artistic, creative industries and regular new businesses.

In the UK in the last decade, dozens of artist-run galleries have emerged, many inhabiting post-industrial spaces, often part of a new creative quarter development or designated cultural industries district. In Europe, some of these enterprises have radical origins; some were simply city urban cultural policy innovations; others were local enterprise initiatives. These include Berlin (Tacheles), Grenoble (Quartier Berriat), Helsinki (Cable Factory), Lausanne (Flon), Marseille (Friche Belle-de-Mai), the Dortmund ' $U$ ' and Birmingham's Custard Factory. Yet, whetever interconnections contemporary art galleries increasingly maintain with the creative industries, the 'artist-run' phenomena has a distinct provenance and history. While a rhetoric of artistic freedom and autonomy may be common to all, the artist-run gallery is a hybrid entity (Batia 1979; Blessi et al. 2011; Bronson 1983; Cooke 2006; Tremblay, Pilati 2007). While many attract public funding, many artists choose this pathway for the way it cuts the 'middle-man' of the art dealer out of the economy of art, integrates production and exhibition, thus allows for on-site retail and thus greater market exposure. Many artist-run galleries expose their production (studio) areas to casual visitors or 'passing trade', others operate as a 'cluster' or traditional cottage industry with factory 'outlet' or store dimension. Others are more like cultural or community arts centres, with multi-purpose facilities available for rent. In the USA, the term more commonly used is 'artist-run spaces'; in Australia we find 'artist-run initiatives' (ARIs); and Canada is home to numerous and very popular 'artist-run centres'. On one side of the political spectrum, they can take the form of radical activist communities, collectives or squatter colonies, interrupting the symbolic order of cultural production in a given urban location; on the other side, they provide a haven from politically-Left art world values, stylistic trends and dealer-dominated models of patronage. They can preserve less than fashionable work- ing methods of indigenous crafts, the artisanal values of renaissance workshops, or the collective production models of mediaeval guilds. Our case here, EP, is a gallery that sits in a large ex-cabinet making facility, next to other functioning industrial units, where the clatter of mechanics and machinary can be heard by the art viewer throughout the day. Suitably, perhaps, a craft-inspired attentiveness is paid by EP to the processes of contemporary curatorial techniques, equally balanced with a strategic concern for the role of the gallery in the urban development of the district.

As noted by many urban cultural analysts, contemporary art can act as unwitting catalyst for gentrification. Whatever their economic deprivations and lack of revenue-generating power, the artist is visual signifier of privileged consumption and to some extent can mediate the penetration of exogenous capital into deflated property markets (Miles 2005; Van Heur 2010). New art galleries, alongside cafes and clothing boutiques, are a common ingredient of the rehabillitation of historically defunct urbanity. The artist's identity as a professional, however, remains insecure, if not perpetually devalued.

There is all too little research on the role of contemporary art in the neoliberal city. Where global capital demands flexible, imaginative and hyper-mobile subjectivities for its mechanisms of economic reproduction, the organisational expanse of the art world, with its cheap, educated and highly dedicated labourforce, is naturally compatible. The so-called 'culturalisation of the economy' and the 'economisation of culture' (Lash, Urry 1994) have generated visible symmetries between the 'soft' power of culture and hard economics of urban life, where both work together to facilitating the convergence of public and private goods, and political interests in a diversity of revenue sources (Hutton 2008; Scott 2000). Culture has become new open marketing platforms, spaces of conspicuous luxury consumption, non-tangible capital distribution and added value to property, brand and service provision in the new symbolic landscape of the city (Grodach, Silver 2012).

As some have noted, the business entrepreneur the central agent of the capitalist post-industrial economy - shares essential characteristics with the avant-garde artist. With Kjell Nordström and Jonas Ridderstråle we may be inclined to celebrate the achievements of 'Funky Business' in a more stimulating world of 'Karaoke Capitalism', but the integration of commerce and aesthetics in the 'Experience Economy' presents major challenges for the artist (Nordström, Ridderstråle 2004, 2007; Pine, Gilmore 1999). Where creativity, new ideas and new visual languages, were the exclusive preside of art and culture, the younger generation are more inclined to locate them in com- 
mercial and entertainment-based digital media. While this comparison may seem inapposite, Boltanski and Chiapello's historical study, The New Spirit of Capitalism (1999) demonstrated the extent to which the corporate management culture of the 1990s (across all sectors of industry) absorbed 'culture', to the extent that the corporate imagination now craves creativity, risk-taking, flexibility, polyvalency, radical autonomy, mobility and openness to change. What terms or language are left for radical artistic enterprise?

While throughout the 1990s, contemporary art successfully competed with popular culture and media with the help of the spectacle, controversy and artist celebrity cultivated by the new museums of contemporary art, one issue remained: art's 'public' dimension. While an historical anachronism to some, more and more artists have become concerned with the 'political' relationshiop between art and 'public' culture (public funds, public space, institutional resources and the right to petition authorities). In their publications and publicity, EP continually articulate a conviction that contemporary artistic culture is a 'public good' necessary for the health of the city. It is under threat through corporate privatisation and neoliberal political management of the city's assets. Art galleries are the guardians of the city's culture. And yet, in an urban economy where public and private are merging, and their discrete jurisdictions are dissolving, how can 'public' maintain a substantive political agenda? EP is a 'public' gallery in 'private' facilities (albeit owned by a business entrepreneur operating with an explicit motive for the 'public good' (Gray 2002)). Arguments for 'public culture' so often remain partisan rhetoric, not a strategic policy alternative. Our task is to theorise the complexion of public agency for contemporary art in the neoliberal city.

\section{The case of Eastside Projects}

EP began as a collaborative project between five artists and a designer, and continues to be run day-today by the artist who conceived the gallery concept, Director, Gavin Wade, and Associate Director, Ruth Claxton. As managing directors, Wade and Claxton are supported by a small group of up to eight staff, some of whom may be artists, but all of whom participate in the creation and recreation of the art space. EP's building facility maintains its industrial character, where any form of internal partition or external cladding is provisional. With each of the four to five major exhibitions a year the space completely changes, in shape, form and appearance, but it never loses its physical connnection to the functioning industrial units around it (Wade et al. 2011).

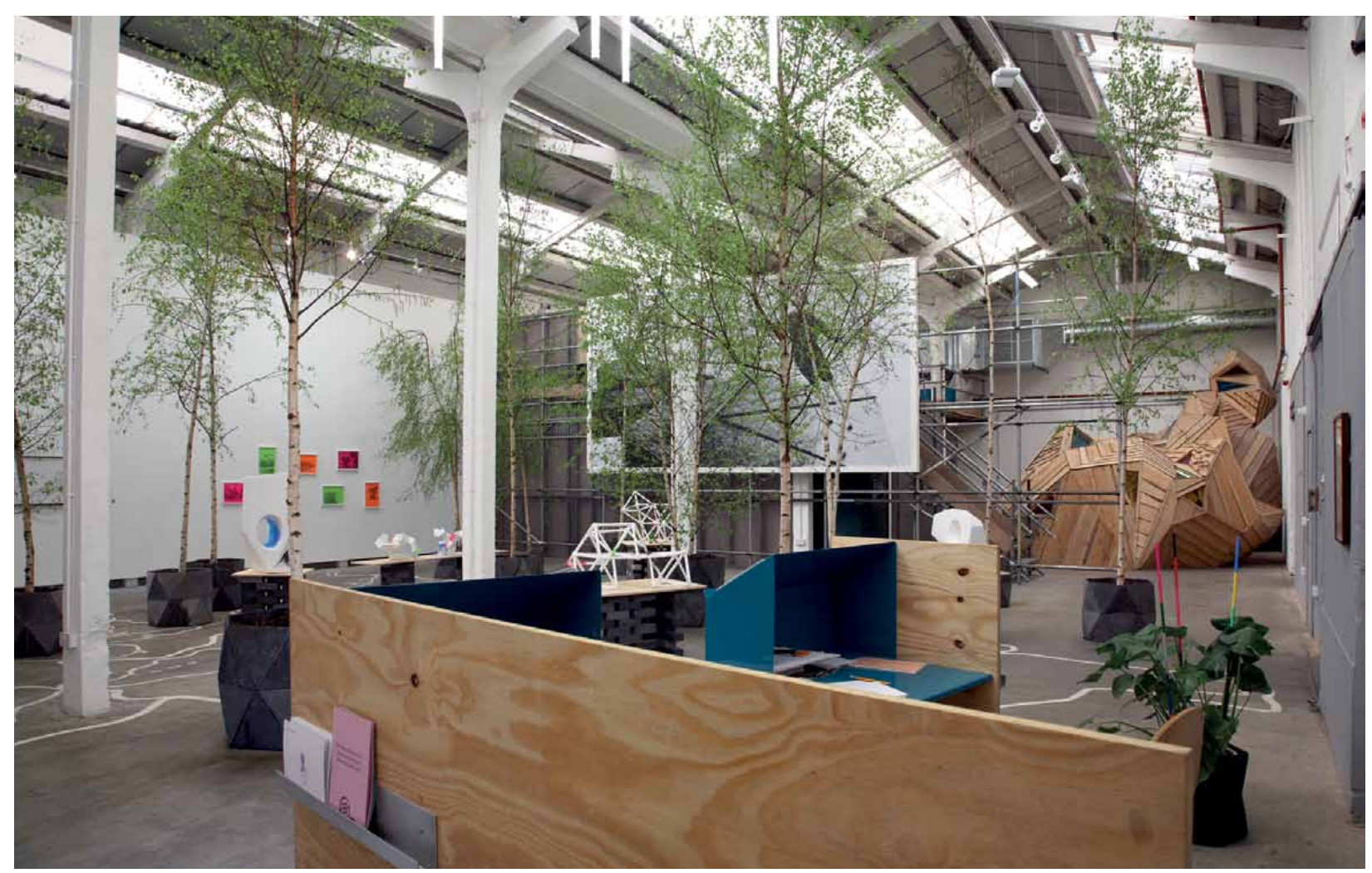

Fig. 2. Eastside Projects (interior) 
Given its routine public funding, not to mention its geographic proximity to one of Europe's largest creative industries quarters, the Custard Factory, EPs position within the institutional matrix of city culture may seem entirely favourable, if not stable. Just past its fifth year, EP are now attracting various requests for consulting work in the city: offering their expertise for cultural events, public arts commissioning or urban development policy. They have been active in the cultural initiative, 'We Are Eastside', comprising the cultural actors in the area who through collaboration attempt to gather a local community of visitors and participants, and influence policy makers as well as the general perception of the area within the city. EP also convene a members-only group called Extra Special People (ESP). Aiming essentially to develop young artists alongside established artists and the arts infrastructure in Birmingham, ESP is a platform for events ranging from artists' and curators' talks, peer reviews, visits to galleries in other cities, as well as parties and music based events. Yet, EP rent their building facility, have few permanent assets, house no permanent collection of art works; they rely on current networks of contacts, the collaboration of visiting artists, and the local provision of services for exhibition installation, IT, audio and visual requirements..

The framework for this evolving strategy is routinely publish as successive 'drafts' of the 'Eastside Project's User's Manual'. The second draft stated that the Manual "... explains what the space is made of, how it was set up, who it is for, how it can be used and what it can offer. Spaces do not often come with instruction manuals. Eastside Projects was designed from experience and speculation on future publics, inhabitants and workers of the space, to expose its specific context and encourage its use. As would be necessary for operating a machine or learning a subject a manual may be necessary for the full use of Eastside Projects. In this way we seek to open Eastside Projects to new forms of engagement" (Eastside Projects 2008: 1). The manuals are manifesto-like, and define shared reference points for visitors, collaborators, workers as well as funding agencies. The fifth draft User's Manual expressed the intention to incorporate the methodologies of art making at all levels of the functioning of the organisation' (Langdon 2012: 25). The management, organisation, marketing, retail, PR, becomes part of (or the subject of) art - and becomes subject to the same questioning and interrogation as curatorial questions about art. Whereas for most galleries, management and communications are outside the realm of cultural production; for Eastside, at least theoretically, they are intrinsic to the way the 'public goods' of the art and the public space of the gallery functions within the urban space of the city. Iterated by artist-architect and co-founder Celine Condorelli, EP's three main principles are:

1. Expanded program: Eastside Projects considers design, organizational structures, and architecture to be an integral part of its program.

2. Continuous evolution: each aspect of the gallery is in process and constant evolution.

3. Cumulative space: work may remain; exhibitions leave traces and become existing conditions for the next works to take place in (Condorelli 2010: 85).

EP's gallery administration is convened through three roles: exhibitions and activities (production), core curatorial competencies (operation) and public outreach and publicity (distribution). However, the production, operation and distribution is a collaborative venture, as EP's small team work across each other and together, with routine proximity of workers, visitors, partners and artists. EP's day-to-day work is fluid and sustained by interpersonal interaction and constant discussion. The fifth draft of the gallery's User's Manual states that 'Eastside Projects seeks to continuously question its status as an organisation and respond to the pressures of becoming an institution' (Langdon 2012: 26-7).

There are three aspects of EP I wish to draw attention to. While, as stated above, they occupy a relatively uncontroversial position within the funding landscape for public culture, I would argue they are developing a critical approach to space - 'critical' in an immanent sense and not involving an explicit position-taking of opposition or resistance. The first aspect involves the function of the 'art' or work of art, or art object. EP, as a gallery, is not a showcase or 'display box' for artists. It is an ongoing 'project', whereby the art is itself a medium for the exploration of the urban conditions of possibility for the space. While visiting exhibiting artists work with the curator (centrally, Gavin Wade) to construct an exhibition of their work, the exhibition itself is conceptually oriented towards the gallery's ongoing exploration of its spatial ontology: what is the public function for new art space in the city? This began with the first show in September of 2008, This is the Gallery and the Gallery is Many Things. The concept was influenced in part by the small Peter Nadin Gallery in New York, where in 1978-1979, Nadin, Christopher d'Arcangelo and Nick Lawson organised a continuous exhibition called 'The work shown in this space is a response to the existing conditions and/or work previously shown within this space' (Eastside 2013a). Including artists Daniel Buren, Dan Graham, Louise Lawler and others, 
the art show featured a statement of intent: 'We have joined together to execute functional constructions and to alter or refurbish existing structures as a means of surviving in a capitalist economy' (Burrows 2013: 15; Eastside Projects 2013a).

Wade has defined the successive exhibitions of EP in terms of a continual reconstruction of the strategic approached to exhibiting art for the public, and conceptually an "evolution", a central plank of which is the 'function shows'. These shows have included Sculpture Show, Abstract Cabinet Show, Curtain Show, Painting Show, Book Show, Narrative Show and Puppet Show and have all generated a dialogue on production, where the locus of concern is shifted from the individual work of art, as it is the ego of the artist, to foreground "what artists can do to create space, create meaning, create the gallery". Within this, "we count movement, space and architecture, and time and memory... as materials for making art", states Wade (quoted in Burrows 2013: 15). The next scheduled show in this series is Trade Show, developed out of research by Wade, with artist Kathrin Böhm, exploring alternative trading economies, "how art has always been embedded in new evolving relations of exchange", and what that means for an art space in the urban economy. How can necessary forms of commercial exchange be intergrated into broader modes of socio-urban development?

A second aspect of EP's work is the role of narrative. Narrative is a deliberate curatorial strategy, visible in every aspect of the gallery, from the front desk to the office space, where the material fabric is comprised of components and objects that have a history and significance in the evolution of the gallery space. The new bar-cum-seminar space - called Black Pleasure - has a historical origin in two sculptures by Heather \& Ivan Morison, one of which in 2008 became EP's previous office space, Pleasure Island. This approach is indicative of Wade's intention "to make something that is functional in the gallery, which is also art", and where the functional space is "a new public space within the gallery... a bar, cafe area, seminar space, party space, office break out space", and in which every material used "has their origins in other art works, exhibited around the world, and takes you on a journey that is the history of the gallery." The gallery thus forges successive "visual languages, which articulate particularities of lifestyles in specific times and places", opening up the "thinking space" of EP as a public gallery.

The 'narrative' is the temporal dimension of EP and is manifest through the conceptual framework of each exhibition, which is conceived as a response to the space, and also with the consistent statements, publications and seminars, and the consistent way in which the staff team rationalise their work and discuss it with participants and visitors. Each visiting artist leaves behind something from their exhibition (such as an art work), or engages in a collaborative activity while resident (like a publication). With each exhibition cycle the lexicon of terms that EP use to refer to the space is extended, and the 'project' continues. In Gavin Wade's terms, the art space is in a process of "becoming itself", and when it comes to the matter of art, the city needs a space for thought. The very identity of EP is an open question, as the city boundaries have been altered whereby the gallery now finds itself in the district of Digbeth not Eastside.

Eastside was never an official, cartographically assigned region of the city; it was a local identification, a kind of 'urban myth'. The central exhibition of Autumn 2010 featured Dutch artist Jennifer Tee; called Local Myths, it explored the material culture that is the necessary precondition for the evolution of a sense of place or place identity. For EP is a developing material culture for the creation of a place for art - if animated by the contradiction between the experience and historicity of Eastside as a 'local' place of both labour and habitation, and the policy-designation of Eastside as a bounded city district. From her exhibition, Jennifer Tee left behind the central work, a marble column inscribed with 'Urban Myths'. Wade has negotiated its re-siting on the other edge of the district of Eastside. Their own end of the Eastside district is about to be marginalised by HS2, a central Government driven-plan for a super-high speed train line, which will "colonise" the north end of the area for a new high-end integrated commercial office, retail and 'cultural' quarter.

The third characteristic of EP I want to draw attention to is their recent shift in priorities. As Wade indicates: "We started through a will to be part of the process of urban change". Whereas now, "we have become less interested in the formation of physical change, and more in policy change... and the "actual mechanisms" through which the city works as an urban space: it is "a change in values and political imagination". Policy priorities in the city, like all cities that are experiencing acute economic recession, now favour single projects offering the potential for big business, foreign direct investment, a high return and taxable advantages. The political will for consistent, integrated, urban cultural policy, has stalled.

The way EP conceptualise its operations - in terms of the classical triumvirate of nineteenth century economics: production, operation, distribution - generates an intentional sense of symbiosis with the struggling industry of this district of the city. The symbolic 'industrialisation' of art (its location in, and occupation 
of, post-industrial buildings) is a tacit re-inscription of artistic creativity within the frameworks of socially-transformative labour, evoking earlier avant-garde and the neo-avant-garde artist-engineers, from Constructivism to Post-minimalism. As Wade observes: "Historically, there has always been a problem with artistic labour... with the identity of the artist". Here EP appeal to the need for the city to re-frame its concept of industry, where the task of building industry itself has been supplanted by a policy-enforced priority for 'business'.

Given the city of Birmingham's history, as a city without ancient roots and constructed between the late eighteenth to the late nineteenth century industrial revolution, its historical laissez faire approach to economic development has been facilitated by equally laissez faire methods of urban planning. In the urban policy imagination, the city has always been an industrial tabula rasa: one economically non-viable building edifice can be completely erased to be replaced by the next. The recent rebuilding of the city's central public library, notwithstanding the spectacular new architecture, is symbolic of the city's reluctance to retain and maintain a continuous narrative of its history and with it a reflexive understanding of the processes of, and conditions for, (re)industrialisation (Birmingham City Council 2010).

In the sixth and most recent 'draft' of EP's User's Manual, the gallery engages with the historic brand and motto of the city of Birmingham. Ironically (for Wade, sincerely and didactically) it is designed as a children's storybook. It takes the city's motto 'Forward' - which originated in the industrial revolution-era, along with its original brand symbol of the hammer; it tells the simply story of the city's evolution. The story is as follows:

'The city wasn't always here. How did it become what it is today? The city is shaped by The Hammer. The Hammer's motto is 'Forward!' The Hammer has two supporters. They are The Artist and The Engineer. Each day they put the city together. But at the end of each day, The Hammer cries 'Forward!' The Hammer clears away the city. He buries and flattens. He makes a new foundation. The next day, The Artist and Engineer put together a new city. One night, after The Hammer has cleared the city, The Engineer sees something left over. The Artist has an idea. The Artist and The Engineer imagine a new way of building with leftovers and layers. Can they persuade The Hammer not to flatten the city? The Artist says, 'We could build on top of, around, over, and through'. The Engineer says, we could recycle and upcycle'. The Engineer says, 'We could build a city with memory'. The Artist says, 'To do this we will need a new motto'. They talk all night with The Hammer. One thousand ideas! One hundred ideas! One idea! The next morning they are ready to make their announcement to the city. The new motto of the city is 'Layered'. Welcome to our new layered city! The city records its own history. Nothing is forgotten' (Eastside Projects 2013b).

The childlike simplicity of the story - distributed around the city in a colourful booklet - articulates the way corporate neoliberalism still operates with the myopic and linear logic of industrial modernisation. Yet the story side-steps the modernist opposition of artist and engineer, underscoring the necessity for instrumentality, introducing a new alliance for the city. For both artist and engineer understand the city, and together demand to engage in deliberations with the Hammer, emerging with a new approach. This is articulated in the new motto 'layered'. The chronic, unreflective, 'cycle of urban erasure and renewal' is now over.

This simple philosophy of urban planning is expressed in EP's own curatorial strategy: every material component of each exhibition is 'upcycled' and used in the next, added to the fabric of the building, where memory and reflection on identity and the material conditions of development is maintained. The point is, the new Manual states, 'we believe art and artists could be involved at every level in the planning and operation of the city'.

\section{Discussion: policy space}

We need now to stand back and attempt to conceptualise EP's approach to their space and in doing so venture to construct an elementary theoretical framework for the public agency of art in the neoliberal city. I begin with Marc Augé's now well-known term 'nonplace' [non-lieux] (Augé 1995). The new post-industrial or 'warehouse style' art spaces bear some strong relation to Augé's new spaces of 'supermodernity' within advanced service industry economies. Where airports, superstores, international hotel chains, are all characterised at once by an impressive strategic function, strategic integration of service management and consumption, architectural creativity and sophisticated design, they do so through emptying out the substantive identity, actual material production and social community that make for an actual 'place'. Nonplaces are islands of highly refined and defined specialist activity, whose tangible form is endlessly mutable in response to the perpetual demands of global capital. Non-places often simulate their own sense of 'locale' with a transitory community of workers operating in the nexus of a global integration of supply and demand. Yet non-places are vacant of any intrinsic potential for social reproduction, autonomy, agency or actual community (and thus actual industry). 
There is a sense in which the new global 'warehouse style' art galleries are the non-places of contemporary culture. Generic place-less spaces, separated from their urban environment as ciphers of global cultural capital, even local residents experience its spaces as cultural tourists. There is a sense in which EP participates in this globalised art world, with its visiting international contemporary artists, few of whom could remain long enough to gather substantive knowledge about the city, and whose exhibited work cannot but create a realm of experience quite separate from its immediate urban context. Stepping out of the dark street of Heath Mill Lane, with its industrial workshops, and into the gallery of extraordinary displays of art, suggests 'nonplace'. Yet, I want to suggest that EP inverts the logic of the non-place, and with it the spatial logic of globalisation that pervades every fashionable contemporary gallery with such ease. Rather than simply showcase international art celebrity, EP uses the themes, issues and ideas emerging from contemporary art's global discourse to animate their own developing discourse on the locale and the city, its values and priorities. The open awareness of the 'global' (manifest in the gallery's art world connections, networks, collaborations and publications) serves to fend off the parochialism so endemic in the public life of the English city.

EP emphasise particular dimensions of its curatorial approach - notably the relation between its materiality (the building, urban location, and physical exhibition materials for upcycling) and temporality (memory, historicity, and the trajectory of urban development). Insofar as the gallery is publically funded, their approach is subject to the routine scrutiny, review and evaluation mechanisms of its sponsoring bodies. My proposed theory of agency will therefore take into account a basic principle of organisational institutionalism, which holds that organisations are less independent actors than variants of existing organisations, and embody the social conventions, rules and norms of such organisational formations (its 'institutional context') (Powell, DiMaggio 1991). However, my account emphasises the innovative, non-typical dimensions of the new art space of EP - it is a deliberate departure from existing professional models. I will locate the institutional context, therefore, not in the organisational field of new contemporary art galleries (in the fashion of 'new institutionalism', for example), but in the conventions, rules and norms that make for the 'public' determinations of art as an object of cultural policy. As quoted above: 'We do not make art for the public. We are the public that makes art... The artist run space is a public good.' (Eastside Projects: http://eastsideprojects. org/about/).
Our concept of agency therefore attends to the political-policy means by which the concept of 'public' is constructed for cultural organisations in the UK. Art organisations are funded according to strategic principles, positioning the organisation with a discourse that identifies that organisation as a suitable mediator of funding agreements, which is to say, a suitable 'object' of policy. To be an object of policy is to be a mediator of the State's own need to exercise and demonstrate representative power. Public culture, as a most visible exercise of State power, is not only an exercise of authority, but of recognition of social needs outside the realm of the market and private interests, that is, within a purely political jurisdiction. Within this jurisdiction, public funds are disbursed through certain mechanisms of evaluation - to achieve public value. Public value is not simply a general identification of a public good or benefit, but an outcome of measurement as conducted by a mechanism of evaluation. Value is a process, product, and source of political validation.

My basis for constructing a theory of agency is an understanding of public culture as an institutionalised realm of State authority, legitimacy and public value. From a critical post-Foucauldian perspective, any manifestation of authority, legitimacy and value by a publicly-funded cultural agency is also a register of the means by which the State maintains and develops its own claims and maintenance of power (the State's own authority, legitimacy, value and are at stake in these three basic conditions of public policy objectivity). However, our theoretical outline does not extend this far: we simply need to understand the terms by which public agency is operative in the new art space of EP.

EP emerged in 2008, at the zenith of the British New Labour Government's cultural policy, propelled as it was by a period of unprecedented investment in public culture (Cultural Trends 2011: 20). New Labour's early adaptation of America's New Public Management (NPM) practices provided the means by which billions of pounds were 'invested' in the arts and culture. NPM permeated the cultural sector at breakneck speed. The historical institutional norms of public organisation were rapidly replaced by management and fiscal arrangements derived from the corporate world (Blaug et al. 2006; Harvey 1989). The subsequent evacuation of historic institutional procedures was not without consequence. The very concept of 'public' was no longer self-evident or the assumed outcome of State patronage: it demanded an extensive ideological reconstruction. This process of reconstruction took one form in the extensive policy guidelines on 'value', both 'public value' and 'value for money', featured as post-facto evaluation mechanisms distributed to every public organisation (Holden 2004). 
There were high level political forces at work in this process, with HM Treasury's bible of public evaluation, The Green Book (which was an evolving document, first emerging in 1992), provided detail on how 'public service agreements' (PSAs) were to be arranged, like corporate contracts between the funding arms of Government and those in receipt of public funds. The cultural sector received its own version in 2004, The White Book, published by the Government Department of Culture, Media and Sport. The cascading stream of politically-inspired monitoring and evaluation methods did not just shape the management of art organisations, but the terms through which they conceived and articulated cultural production, and in time, cultural values and priorities. It was a cultural change in the cultural sector, the extent to which many were blind: this new 'audit culture' was subject to critique (Belfiore 2004), but ushered in a new administrative normativity.

The bureaucratic rationality of audit culture had its own ontology of space and time: validated forms of organisation were branded, defined by their services, managed by specialists who inhabited closed professional networks, and set forth on a prescribed trajectory of production of pre-defined 'public value'. Ideologically, audit culture was difficult to combat, as it was framed in the language of social justice - political transparency, public accountability, participation, enablement, and empowerment; it was a precondition of public funding (Mirza 2012). By 2006, the 'public' dimension of the arts and the work of cultural organisations was heavily circumscribed by the audit regime, spawning organisational models that framed cultural production as 'cultural service provision', in turn provoking a fundamental intellectual shift in the minds and professional interests of cultural workers. Through the last fifteen years (largely with the advent and decline of the UK's New Labour Government (1997-2010)) a range of further policy initiatives have been involved in making certain 'agency' options available for new art spaces (ACE 2006). The options concern only 'contributory' roles to the urban economy, usually where the arts provides resource for the city's other service providers - for community, education or neighbourhood cohesion projects, the civic brand effort, cultural tourism, place-making urban planning or cultural landmarking.

This new organisational formation for contemporary art required cultural workers with the necessary management, financial and bureaucratic training, and facilitating the provision of a wide range of cultural services, from commissioning consultancy, project management, research, evaluation and reviewing, social, community liaison, retail, hospitality, catering; games and entertainments, as well as education. Many public art institutions were under obligation to adopt a range of service practices that could not be sustained with fluctuations in public funding (and recent recessionary decline in funding): after all, service providers appear and disappear according to the cycles of supply and demand.

Between 2000-2010, public culture in the UK exhibited cycles of overproduction and overconsumption as characterized the compulsive 'growth' tendencies of market capital. Audit culture ensured that the organisational formations of public culture never exceeded its ability to monitor them, which meant that organisational innovation was only developed on the level of the service. It remains unusual to find an art organisation equipped with expertise sufficient for policy interventions in local urban-economic development, or an institution that maintains a forceful political presence in the public policy-making realms of the city.

In an era of austerity and decline in public funding for culture, we find ourselves with a pressing question: is public agency for contemporary art available without State mediated authority, legitimacy and value?

\section{Conclusions: anti-space}

The term 'anti-space', that is the title of this paper, is adapted from Robert Morris's well-known essay of 1968, 'Anti-form' (Morris 1968), and is my means of theorising the inverted non-place of EP. In this essay Morris attempts to construct a new concept of art, turning his back on successive traditions of visual or pictorial representation and their institutionally framed display or exhibition. Morris's anti-form places the emphasis on the material conditions of the relation between the creative subject and the specific place. In practice, in New York in 1968, Morris wanted to open up the process of art making to the specific locale of the space, and the air, moisture, walls, floor, and other phenomenal conditions of location, which all became internal to the 'work' (and later, for some, was called 'process' art). Anti-form was bought at the cost of embedded value - the institutional guarantee of the intrinsic value of a recognised 'work of art'. It signalled a re-investment in 'the process of "making itself"... in order to 'recover process and hold onto it as part of the end form of the art work' (Morris 1968: 43). This process, for Morris, does not proceed from preconceived 'models', established styles, or already conceptualised aims. There is no specific artistic 'form' in view: 'The perpetuation of form is functioning idealism' for Morris. 
'Idealism' for Morris signified the rule of conceptual models of production, value and action, which were preconceived, invented elsewhere, by others, and prohibitive of a co-creative relationship between an individual human subject and the specific space they were inhabiting at a given time. The thrust of Morris's argument is that most of what we value in art is actually of 'value' because of its role in art's institutional re-production and not in the creative production of human knowledge through an engagement with its environment. Most of what we value in art is what can and has been institutionalised within successive and bureaucratic processes of the appropriation of culture. This has repressed art's potential for engaging with actual material existence.

If 'anti-form' indicated a process, or dynamic relation, between the human subject and their material conditions of artistic labour within the confines of a specific space, then my concept of 'anti-space' reiterates this process on the level of the organisation. The space of art becomes an organisational act in a specific urban locale. Resisting the imposition of a priori templates for 'exhibition space' or 'art gallery' (and the cognitive implications of these models or institutional architypes of cultural 'form'), the space itself is conceived as a dynamic agency, embedded in a process of uncovering the material conditions of its own practice within the discursive imposition of 'public' by State audit culture. Anti-space involves questions of agency, which are intrinsically related to the materiality and the temporality of art in a specific urban place. EP occupy their location, demanding to know what role art space can potentially play in urban development (its intellectual-policy formation as well as physical change).

EP explore agency (the authority or authorising power required to create a 'public' entity). This is done not through outright opposition (which would place them outside the policy confines of public authority). My term anti-space, where 'anti' or 'ante' (in Latin) suggests a surrogate or provisional space. It is through their refusal to separate management and art, marketing, PR and art, the demands of artistic experimentation and the formation of an organisation, that the gallery becomes a kind of fictive heuristic for identifying the power of policy to delineate activity and fix limits. EP further attends to the materiality of art: how the physical emergence, display, and experience of art is coextensive with the building and with the location of the gallery Their curatorial practice thus exposes the prescribed institutional 'form' of the art gallery, what it is to be an art gallery, and thus to exercise the means of legitimacy. In the frameworks of policy, an art organisation is validated through its delineation of its professional specialisation (in art), strongly defining the inside and outside of the institution (if only then under a perceptual demand to breach that boundary through constant 'outreach' activities and contributions to the city's public services). EP are interdisciplinary, collaborative, both artists and curators, designers, and engaged discussants with ordinary residents and policy makers alike within the city. Lastly, Eastside explore the temporality of the gallery, where the gallery is reconceived as an urban space coextensive with the spaces (social as well as cultural) of the city, and can play a role in the city's erasure of its historicity, its repression of memory. EP's art space rehearses the various planning mechanisms by which a city can 'layer' its memory and find value in its own convulsive evolution.

The value of 'anti-space' is thus lodged in the dynamic of process, and not in a discrete series of final 'products'. Within the neoliberal city, the State generally prefers 'depoliticised' cultural space, and not space that contends with the 'public' discourse that define the public (and to some extent, the urban culture of the city). This is attested by the lack of involvement of contemporary art institutions in the formation of a city's urban policy.

What form of critical agency, then, is possible for contemporary art in the city? Our study above has observed in our case of EP a spatial ontology involving a triangulation of agency, materiality and temporality, which in turn have the potential to address the spatial determinations of art in the city through the public policy diktat of authority, legitimacy and value-production. EP venture to propose that the ontology of an art space should be created by art itself (not imposed, or imported). The project of creating an art space will be at once a dissolution and reconstruction of the agency, materiality and temporality of art. It is a living discourse on the limits of the public policy imaginary.

In the concluding Diagram, I configure these thoughts in a way that hopefully becomes useful in providing a critical-analytical framework for researching the spatial aesthetics of alternative art spaces in the neoliberal city more generally. EP's anti-space project is configured by a curatorial mediation of successive art works that developed around the limits of agency, materiality and temporality in that particular place. It identifies and occupies the liminal dimension of that space (of the arbitrary limits of) agency. These are the lines of operation through which authority emerges and is activated in the organisational formation of art: these are the artist's or curator's actions of 'authorising' creativity, exercising professional identities, operationalising the institution of art, its brand positioning, and cultural politics of its relationship to its 'public'. 


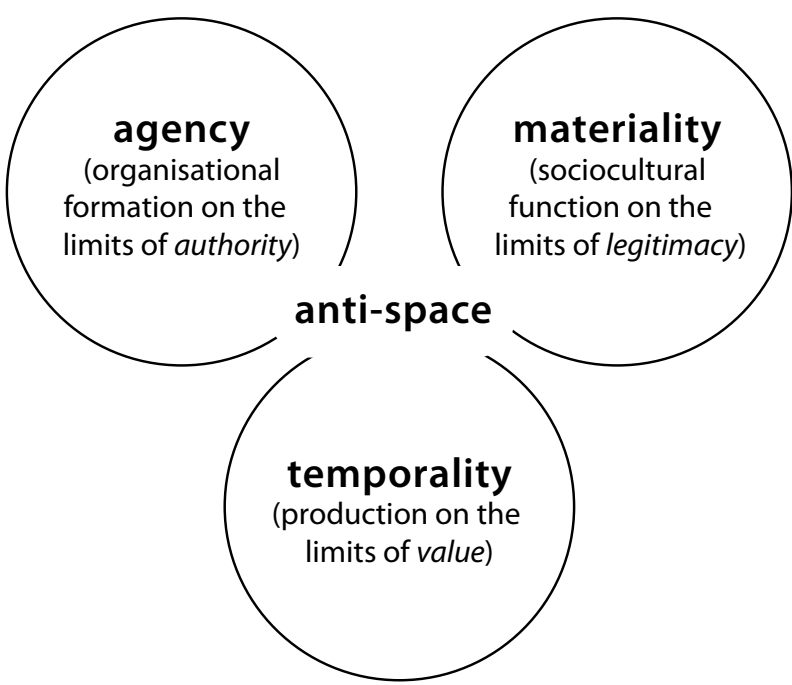

Fig. 3. Anti-space

Second, anti-space identifies and occupies the liminal space (of the limits of) its materiality: the operations of legitimacy in constructing the material conditions of art's production - the symbiotic relation between form and content as it articulates its social function, finance and the institutions strategic relation to the social structures around it. Lastly, it identifies and occupies the liminal space of the limits of its temporality: these are the operations of value in the cycles of production, exchange, market development, schedules and event-driven activities that form art's economy.

To conclude: an 'anti-space' art space will locate the liminal field of discourse and practice available through uncovering the nexus of its conditions of institutional possibility. Art galleries too often repress the political aesthetics of their urban located-ness. Anti-space is a strategic ontology without a planned strategy: it uncovers the direction and necessary demands of its own management though making all of its practices - administrative, organisational, creative - a subject of art, where art defined a broad collaborative project in both using and expose the limits of official agency, institutionalised materiality and authorising temporalities. It takes some effort to keep the art space vacant of meaning and without embedded institutional value, which frames and validates every role and activity. Only by occupying the current institutional-discursive (de)formation of 'public' will we find out the potential of the inner city art gallery.

\section{References}

Arts Council England (ACE). 2006. The power of art: visual arts: evidence of impact, parts 1, 2, 3. London: Arts Council England.

Augé, M. 1995. Non-places: introduction to an anthropology of supermodernity. London, New York: Verso.
Batia, S. 1979. Artist-run galleries - a contemporary institutional change in the visual arts, Qualitative Sociology 2(1): 3-28. http://dx.doi.org/10.1007/BF02390131

Belfiore, E. 2004. Auditing culture: the subsidized cultural sector in the new public management, International Journal of Cultural Policy 10(2): 183-202. http://dx.doi.org/10.1080/10286630042000255808

Birmingham City Council. 2010. Birmingham Big City Plan: The City Centre Masterplan for Birmingham. Birmingham: BCC.

Blessi, G. T.; Sacco, P. L.; Pilati, T. 2011. Independent artist-run centres: an empirical analysis of the Montreal non-profit visual arts field, Cultural Trends 20(2): 141-166. http://dx.doi.org/10.1080/09548963.2011.563907

Bloor, S.; Bloor, T.; Condorelli, C.; Claxton, R.; Wade, G. 2011. Eastside Projects user's manual, draft 4. Birmingham: Eastside Projects.

Boltanski, L.; Chiapello, E. 2005. The new spirit of capitalism. London: Verso.

Bourdieu, P. 1984. Distinction: a social critique of the judgment of taste. Translated by Richard Nice. Cambridge: Mass: Harvard University Press.

Bronson, A. A. 1983. The humiliation of the bureaucrat: artistrun centres as museums by artists, in A. A. Bronson, P. Gale (Eds.). Museums by artists. Toronto: Art Metropole, 29-37.

Blaug, R.; Horner, L.; Lekhi, R. 2006. Public value, politics and public management: a literature review. London: The Work Foundation.

Buddensieg, A.; Belting, H. (Eds.). 2009. The global art world: audiences, markets, and museums. Ostfildern: Hatje Cantz.

Burrows, D. 2013. The gallery is many things. Birmingham: Eastside Projects.

Condorelli, C. 2010. Functional configurations: Eastside Projects as a play in eight acts, Manifesta Journal 10: 84-97.

Cooke, J. 2006. Heterotopia: art ephemera, libraries and alternative space, Art Documentation 25(2): 37-40.

Cultural Trends September-December, 2011. Special issue on New Labour's Cultural Policy and Legacy.

Department of Culture, Media and Sport (DCMS). 2004. The White Book: DCMS guidance on appraisal and evaluation of projects, programmes and policies. London: DCMS.

Eastside Projects. 2008. Eastside Projects manual, draft 2. Birmingham: Eastside Projects.

Eastside Projects. 2013a. This is the Gallery and the Gallery is Many Things, 27 September to 22 November, 2008 [online], [cited 24 October 2013]. Available from Internet: http:// eastsideprojects.org/past/this-is-the-gallery-and/

Eastside Projects. 2013b. The artist and the engineer: Eastside Project's user manual, draft 6. Birmingham: Eastside Projects.

Foucault, M. 1972. Archaeology of knowledge. Translated by A. M. Sheridan Smith. New York: Pantheon.

Grande, N. 2012. Relational Critique, in G. Vaz-Pinheiro (Ed.). Relational spaces: a new expanded field for art and thought. Porto: ArtinSite, 35-39.

Gray, B. 2002. The role of the entrepreneur, in M. Stratton (Ed.). Industrial buildings: conservation and regeneration. London: E \& FN Spon, 109-121.

Grodach, C.; Silver, D. 2012. The politics of urban cultural policy. New York, London: Routledge. 
Harvey, D. 1989. From managerialism to entrepreneurialism: the transformation of urban governance in late capitalism, Geografiska Annaler 71B(1): 3-17. http://dx.doi.org/10.2307/490503

Holden, J. 2004. Capturing cultural value: how culture has become a tool of government policy. London: DEMOS.

Hutton, T. 2008. The new economy of the inner city: restructuring, regeneration, dislocation in the twenty-first century metropolis. London: Routledge.

Langdon, J. (Ed). 2012. Eastside Projects user's manual, draft five (with Gavin Wade, Celine Condorelli, Simon \& Tom Bloor, Ruth Claxton). Birmingham: Eastside Projects.

Lash, S.; Urry, J. 1994. Economies of signs and space. London: Sage.

Lind, M. 2010. Maria Lind: selected writing. Berlin: Sternberg Press.

Miles, M. 2005. Interruptions: testing the rhetoric of culturally led urban development, Urban Studies 42(5/6): 889-911. http://dx.doi.org/10.1080/00420980500107375

Mirza, M. 2012. The politics of culture: the case for universalism. Basingstoke, Hants: Palgrave Macmillan.

Morris, R. 1968. Anti-space, in R. Morris, 1993, Continuous project altered daily: the writings of Robert Morris. Cambridge, Mass.: MIT Press, 41-51.

Nordström, K. A.; Ridderstråle, J. 2004. Karaoke capitalism: management for mankind. London: FT/Prentice Hall.

Nordström, K. A.; Ridderstråle, J. 2007. Funky business forever: how to enjoy capitalism. London: FT/Prentice Hall.

O'Neill, P. 2012. The culture of curating and the curating of culture(s). Cambridge, Mass.: MIT Press.

Pine, J.; Gilmore, J. 1999. The experience economy. Cambridge, Mass.: Harvard Business School Press.

Powell, W. W.; DiMaggio, P. J. (Eds.). 1991. The new institutionalism in organizational analysis. Chicago: University of Chicago Press.

Rand, S.; Kouris, H. 2007. Cautionary tales: critical curating. New York: Apexart.

Scott, A. J. 2000. The cultural economy of cities: essays on the geography of imageproducing industries. London: Sage.

Tremblay, D.-G.; Pilati, T. 2007. Tohu and artist-run centres in montreal: contributions to the creative city?, Canadian Journal of Regional Science 30: 337-356.

Van Heur, B. 2010. Creative networks and the city: towards a cultural political economy of aesthetic production. Bielefeld: Transcript Verlag.

Vickery, J. 2013. Interview with Gavin Wade, 5 November, 2013. Eastside Projects, Birmingham.

Wade, G., et al. 2011. Brief report on activities. Birmingham: Eastside Projects.

\section{JONATHAN VICKERY}

Associate Professor in the Centre for Cultural Policy Studies, at the University of Warwick, Millburn House, Coventry, West Midlands, CV4 7AL, UK. E-mail: j.p.vickery@warwick.ac.uk

He has been a Henry Moore post-doctoral Fellow (University of Essex), and a Lecturer in Contemporary Art at the University of Warwick. He was a co-editor of the journal Aesthesis, is now Chair of the international Art of Management and Organization. He is Director of the new masters program in Arts, Enterprise and Development. His most recent publication is (with Ian King) Experiencing Organisations (Libri: Oxon). 